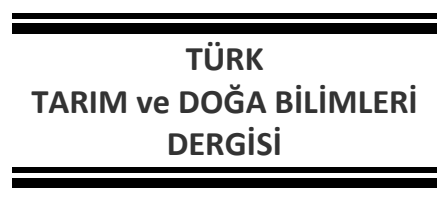

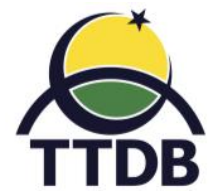

www.dergipark.gov.tr/turkjans

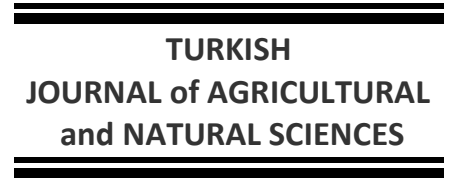

Araştırma Makalesi

\title{
Çanakkale Boğazı (Kepez) Midye (Mytilus galloprovincialis L., 1819) Örneklerinde Ağır Metal ve Antioksidan Enzim Düzeylerinin Mevsimsel Değişimi
}

\author{
Neslihan DEMiR ${ }^{1 *}$, Gülsüm AKKUŞ² \\ ${ }^{1}$ Çanakkale Onsekiz Mart Üniversitesi, Fen Edebiyat Fakültesi, Biyoloji Bölümü, Çanakkale, Turkey \\ ${ }^{2}$ Çanakkale Onsekiz Mart Üniversitesi, Fen Bilimleri Enstitüsü, Biyoloji Anabilim Dalı, Çanakkale, Turkey \\ *Sorumlu Yazar: neslihandemir@comu.edu.tr
}

Geliş Tarihi: 13.08.2018

Düzeltme Geliş Tarihi: 03.10.2018

Kabul Tarihi: 09.10.2018

\section{Özet}

Bu çalışmada, yoğun bir deniz trafiğine sahip olan Çanakkale Boğazı Kepez kıyılarındaki ağır metal kirliliğinin midyeler üzerindeki etkileri araştırıldı. Bu amaçla, Akdeniz Midyesi (Mytilus galloprovincialis) solungaç, hepatopankreas ve kas dokularında toplam protein (TP), süperoksit dismutaz (SOD) ve katalaz (CAT) düzeylerindeki değişimler incelendi. Mevsimsel farklılıkları değerlendirebilmek için dokulardaki kadmiyum (Cd), bakır $(\mathrm{Cu})$, demir $(\mathrm{Fe})$, kurşun $(\mathrm{Pb})$ ve çinko $(\mathrm{Zn})$ ağır metallerinin birikim düzeyleri de tayin edildi. $M$. galloprovincialis örneklerinin solungaç, hepatopankreas ve kas dokularındaki ağır metal miktarlarının (sonbaharda hepatopankreasta ölçülen $\mathrm{Pb}$ değeri hariç) kabul edilebilir değerlerin altında olduğu belirlendi. TP miktarı, en yüksek hepatopankreas dokusunda sonbahar mevsiminde görüldü. SOD aktivitesi, ilkbahar mevsiminde daha yüksek görülmekle birlikte solungaç ve kas dokularında mevsimsel olarak anlamlı farklılık gözlendi $(p<0.05)$. CAT aktivitesinde solungaç ve hepatopankreas dokularında sonbaharda ilkbahara oranla belirgin ve anlamlı bir düşüş görüldü. Belirlenen farklılıklar, antioksidatif savunma mekanizmalarının ağır metal konsantrasyonlarıyla güçlü bir korelasyon gösterdiğini ve sucul kirliliğin belirlenmesi ve engellenmesinde enzimatik aktivitenin en genel belirteç olduğunu ortaya koydu.

Anahtar kelimeler: Ağır metal, antioksidan, CAT, Mytilus galloprovincialis, SOD.

\section{Seasonal Variations of Antioxidant Enzyme and Heavy Metal Levels in Mussel (Mytilus galloprovincialis L., 1819) In Dardenelles Bosphorus (Kepez)}

\begin{abstract}
In this study, the effects of heavy metal pollution on mussel have been investigated in Kepez, Çanakkale Bosphorus, where has busy sea traffic. For this purpose, changes in total protein (TP), superoxide dismutase (SOD), and catalase (CAT) levels in the gills, hepatopancreas and muscle tissues of the Mediterranean Mussel (Mytilus galloprovincialis) samples investigated. The levels of cadmium ( $\mathrm{Cd}$ ), copper ( $\mathrm{Cu}$ ), iron ( $\mathrm{Fe}$ ), lead (Pb) and zinc $(\mathrm{Zn})$ heavy metals in the tissues were also determined to evaluate seasonal differences. The results exhibited that $\mathrm{Cd}, \mathrm{Pb}, \mathrm{Cu}, \mathrm{Fe}$ and $\mathrm{Zn}$ concentrations of gills, hepatopancreas and muscles of $\mathrm{M}$. galloprovincialis samples were under allowable values (except from $\mathrm{Pb}$ level in hepatopancreas in autumn). TP concentrations were higher in autumn in hepatopancreas. SOD activities were also higher in spring and levels of muscles and gills activities were significantly different in the spring and autumn $(p<0.05)$. Higher CAT activity was measured also in spring although CAT levels of the hepatopancreas and gills were significantly different in the samples collected. The differences indicate that antioxidative defence mechanisms were strongly correlated with heavy metal concentrations, and enzymatic activities are the most common bioindicators for determination and prevention of aquatic pollution.
\end{abstract}

Key words: Heavy metal, antioxidant, CAT, Mytilus galloprovincialis, SOD. 


\section{Giriş}

Kepez, Çanakkale Boğazı'nda önemli bir konuma sahiptir. Kuzeyde İstanbul Boğazı aracılığıyla Karadeniz, güneyde ise Çanakkale Boğazı aracılığıyla Ege Denizi ile bağlantılıdır. Dolayısıyla hem Ege Denizi hem de Karadeniz akıntıları bu bölgeden geçer ve Çanakkale Boğazı'nın kirlenmesinde önemli bir unsur teşkil ederler. Bu bölge uzun yıllardır; evsel, tarımsal, endüstriyel atıkların yanı sıra Çanakkale Boğazını kullanan gemilerin slop, sintine atıkları, slaç ve atık yağları ile de kirlenmektedir. Boğaza bırakılan atık suların içeriğindeki toksik bileşikler, ağır metaller ile azotlu ve karbonlu organik ve inorganik bileşikler, sucul organizmaların dokularında birikerek ya da organik, inorganik partiküllere tutunarak, uzun yıllar bozulmadan ortamda kalabilmekte ve biyota için potansiyel risk oluşturmaktadırlar (Miniero ve ark., 2003; Özden, 2005; Özden, 2013).

Ağır metaller, ciddi sorun oluşturan kirleticiler arasında yer almaktadır. Ağır metaller sucul canlılara solunum ve sindirim sistemi yolu ile ya da deriden ve mukozadan geçebilir. Akuatik organizmalar, geniş ve ince bir yüzeye sahip olan solungaçlarıyla partikül şeklindeki metalleri, suda hazır çözünmüş metalleri ve askıda bulunan maddelerin alımını gerçekleştirmektedirler. Su ve besin yolu ile doğrudan ya da dolaylı olarak vücuda alınan, inorganik kirletici olan ağır metaller taşıyıcı proteinlere bağı bir şekilde dokulara taşınmaktadır (Olsson ve ark., 1998). Ağır metaller, metal metabolizması ve detoksifikasyonu ile ilgili organlarda daha çok birikmektedir (Kayhan ve ark., 2009).

Besin olarak kullanılan önemli bir su ürünü olan Akdeniz midyesi (Mytilus galloprovincialis) temiz ve yarı temiz sularda olduğu kadar yoğun kirliliğin olduğu alanlarda da rahatça gelişebilmektedir. Diğer midyeler gibi besinlerini sudan süzerek alan bu tür, deniz kirliliği incelemelerinde çok iyi bir biyolojik indikatördür (Uysal, 1970; Rayment ve Barry, 2000).

Oksijen, birçok canlının yaşamı için gereklidir, ancak metabolik faaliyetler esnasında üretilen bazı serbest oksijen radikalleri de canlıya zarar verir. Reaktif oksijen türlerinin (ROT) büyük bir çoğunluğu serbest radikallerden oluşur ve normal oksijen molekülüyle karşılaştırıldığında kimyasal reaktiviteleri daha yüksektir (Nawar, 1996). Oksidatif stres, ROT üretimi ile antioksidan savunma sistemleri arasındaki dengenin ROT üretiminin artması yönünde bozulması ile meydana gelir (Brenneisen ve ark., 2005). Oksidatif stres birçok doku ve organda harabiyete, DNA hasarına, kromozomal sapmalara, tümör süpresör genlerde mutasyonlara, kontrol edilemeyen hücre bölünmelerine neden olmaktadır (Schuyer ve ark., 1999).

Süperoksit dismutaz (SOD) enzimiyle gerçekleştirilen işlemler, ökaryotik hücrelerin reaktif oksijen türlerine karşı geliştirdikleri savunma mekanizmalarının başında gelmektedir (Ekici ve Sağdıç, 2008; Yining ve ark., 2011). Süperoksit anyonunu hidrojen perokside dönüştüren SOD metalloenzimi, antioksidan koruma sisteminin ilk basamağını oluşturmaktadır. Katalaz (CAT), hemoprotein özelliğinde olan, neredeyse tüm bitkisel ve hayvansal dokularda bulunan bir enzimdir. Hücreleri, oksitlerin redüklenmesi sonucu oluşan ve ileri düzeyde toksik olan hidrojen peroksitten koruyan CAT, hem-bağlı demir içerir. CAT aktivitesi sonucu $\mathrm{H}_{2} \mathrm{O}_{2}$ parçalanarak serbest oksijen açığa çıkar (Speranza ve ark., 1993; Mates ve ark., 1999). Katalaz normal koşullarda bazı hücre tipleri için gerekli olmasa bile oksidatif stres halinde önemli bir role sahiptir. Ayrıca CAT'ın, SOD'un antioksidant aktivitesindeki hata oranını azaltmak için gerekli olduğu rapor edilmiştir (Fox ve ark., 1998; Yüzügüllü ve Özgel, 2013).

Çevresel metal kirliliğini değerlendirme işlemlerinde özellikle solungaç ve sindirim bezi dokuları, çevresel kirleticilerin enzim düzeylerindeki etkisini gözlemlemek için kullanılmaktadır. Antioksidan savunma enzimleri, protein hasarı ve akuatik canlılardaki diğer parametrelerin mevsimsel ve mekansal değişimi ile deniz kirliliğini inceleme çalışmalarında kullanılmaktadır (Orbea ve ark., 2002; Manduzio ve ark., 2003).

$\mathrm{Bu}$ çalışmada, beslenme şekilleri, uzun süreli ya da letal dozun altındaki konsantrasyonlara maruz kalmaları sonucu savunma mekanizması oluşturmaları ve oksidatif strese duyarlılık gösterdikleri için Mytilus galloprovincialis türü tercih edilmiştir. Bu canlılar; reaktif oksijenlerin hücrede nasıl bir hasara yol açtığı, hücrelerin bu hasara nasıl yanıt verdiği, onarım mekanizmalarının bu hasarı nasıl düzelttiği ve oksidatif stresin nelere yol açtığını anlamada model sistem olarak tanımlanabilmektedirler (Di Giulio ve ark., 1989; Livingstone ve ark., 1994). Solungaçlar kimyasallara ilk maruziyet yüzeyi olarak 
öncelikle araştırılması gereken organlardır. Hepatopankreas, detoksifikasyon işlemlerindeki rolü ve enzim-hormon sentezleme işlevleriyle ekotoksikolojik anlamda oldukça önem taşıyan karmaşık bir organdır. Kas dokusu da midyelerin besin olarak kullanımı anlamında mutlaka dikkate alınması gerekmektedir. Bu nedenle, Çanakkale Kepez kıyılarından toplanan Mytilus galloprovincialis örneklerinde ağır metal düzeylerinin belirlenerek, potansiyel kirliliğin antioksidan enzim düzeylerinde mevsimsel değişiminin araştırılması amaçlanmıştır.

\section{Materyal ve Yöntem Örnekleme}

Çalışma, 2015 yılında ilkbahar ve sonbahar olarak iki mevsimde olarak gerçekleştirildi. Laboratuvara getirilen midye örneklerinin (her mevsim için 50 adet) ölçümleri yapıldıktan sonra pens yardımı ile kabuklar açılıp diseksiyon işlemi gerçekleştirildi.

\section{Ağır metal analizi}

İki farklı mevsimde midye örneklerinden alınan solungaç, hepatopankreas ve kas dokularında ağır metal analizleri Çanakkale Onsekiz Mart Üniversitesi Merkez Laboratuvarında hizmet alımı yoluyla Inductively Coupled Plasma Optical Emission Spectrometry (ICP-OES) (Perkin Elmer, Optima 8000) cihazı ile yapıldı (Siemer ve ark., 1976). Kadmiyum (Cd), kurşun $(\mathrm{Pb})$, bakır $(\mathrm{Cu})$, demir (Fe) ve çinko $(\mathrm{Zn})$ ağır metal sonuçları $\mathrm{mg} \mathrm{kg}^{-1}$ yaş ağırlık olarak hesaplandı.

\section{Antioksidan enzim düzeylerinin ölçümü}

Temel antioksidan enzim düzeylerinin ölçülebilmesi için, solungaç ve hepatopankreas dokularının yanısıra kontrol grubu olarak kas dokusundan homojenat hazırlandı ve sitozolik fraksiyonları elde edildi. Alınan dokular, tartılıp 1:5 oranında homojenizasyon tamponu (0.05 M fosfat tamponu $\mathrm{pH}$ 7.4) ile homojenize edildi. Homojenat iki defa 20 dakika boyunca $4^{\circ} \mathrm{C}^{\prime}$ de $10000 \times x^{\prime}$ de santrifüjlenerek (Hettich Zentrifugen Micro 22R D-78532), elde edilen süpernatantlar 1:5 oranında fosfat tamponu ile seyreltilip $-20^{\circ} \mathrm{C}$ 'de saklandı.

Toplam protein (TP) tayini, Bradford (1976) yöntemi kullanılarak gerçekleştirildi. Midye dokularının protein miktarları mg protein $\mathrm{L}^{-1}$ olarak verildi. Süperoksit dismutaz (SOD) enzim aktivitesi Flöhe ve Ötting (1984) metoda göre tayin edildi. Solungaç, hepatopankreas ve kas dokularının SOD enzim aktivitesine olan etkileri, SOD spesifik aktivite $U \mathrm{mg}^{-1}$ protein cinsinden ifade edilecek şekilde hesaplandı. Katalaz aktivitesi Aebi (1984) metodu kullanılarak belirlendi. Solungaç, hepatopankreas ve kas dokularında tayin edilen CAT aktivitesi, $\mathrm{U} \mathrm{mg}^{-1}$ protein $\mathrm{dk}$ cinsinden verildi.

\section{Istatistiksel analiz}

Çalışmada elde edilen verilerin istatistiksel analizleri IBM SPSS Statistics Version 21.0 paket programı kullanılarak hesaplandı. Dokular arasındaki karşılaştırmada OneWay ANOVA-Tukey testi, mevsimsel karşılaştırmada ise Paired-t testi uygulandı. Deneyler üç tekrarlı olarak gerçekleştirildi ve sonuçlar değerlendirilirken $p<0.05$ değeri istatistiksel olarak anlamlı kabul edildi.

\section{Bulgular ve Tartışma}

Dokularda biriken ağır metaller mevsimsel olarak karşılaştırıldığında, ilkbaharda örneklenen midyelerin solungaç ( $\mathrm{Cd}: 0.515$, Fe:43.201, Zn:14.513 mg kg-1 yaş ağırık) ve hepatopankreas dokularında (Cd:0.179, Fe:18.632, Zn:10.497 mg kg-1 yaş ağırlık) miktarlarının sonbahar örneklerinden (solungaç Cd:0.451, Fe: 37.887, Zn: 7.870; hepatopankreas Cd:0.17, Fe:15.375, Zn:2.257 mg kg-1 yaş ağırlık) yüksek olduğu anlaşılmıştır. Buna karşın $\mathrm{Pb}$ ve $\mathrm{Cu}$ değerleri ise sonbahar mevsiminde daha yüksek oranda tespit edilmiştir (ilkbahar solungaç dokusu $\mathrm{Pb}: 0.226, \mathrm{Cu}: 0.745$, hepatopankreas dokusu $\mathrm{Pb}: 0.135, \mathrm{Cu}: 0.128$; sonbahar solungaç dokusu $\mathrm{Pb}: 0.250$, Cu:0.834, hepatopankreas dokusu $\mathrm{Pb}: 0.525, \mathrm{Cu}: 0.498 \mathrm{mg} \mathrm{kg}^{-1}$ yaş ağılık). Kas dokusunda ise $\mathrm{Cd}, \mathrm{Pb}$ ve $\mathrm{Cu}$ konsantrasyonları sonbahar örneklerinde daha yüksek görülürken $(\mathrm{Cd}$ : $0.125, \mathrm{~Pb}: 0.06, \mathrm{Cu}$ : 0.411; ilkbahar Cd:0.114, Pb: 0.038, Cu: 0.341 $\mathrm{mg} \mathrm{kg}^{-1}$ yaş ağırlık), Fe ve Zn miktarlarında sonbahar mevsiminde azalma görülmüştür (Fe:22.121, Zn:1.094; ilkbahar Fe:24.039, Zn:1.449 mg kg-1 yaş ağırlık). Değerler EFSA (2015) tarafından verilen kabul edilebilinir değerlerden düşüktür.

Özden (2005), Çanakkale Boğazı'nın farklı (Kumkale, Yapıldak altı, Çardak Dalyanı, Hamzakoy, Kilya Koyu, Abide, Seyit Onbaşı, Dardanos ve Yeni Kordon) istasyonlarında Mytilus galloprovincialis'in yumuşak dokusunda ağır metal içeriklerinin mevsimsel değişimlerini incelemiştir. Çalışma sonucunda, ağır metal düzeyleri arasında gerek mevsimsel, gerekse istasyonlara bağlı olarak faklılıklar saptanmıştır. 
Richir ve Gobert (2014) çalışmalarında, Belçika'da Diane göletinde halat sisteminde yetiştirilen $M$. gallaprovincialis türünde $\mathrm{Zn}$, Se, $\mathrm{Cd}$ ve Mo elementlerinin solungaçta diğer dokulara göre daha fazla biriktiğini belirtmişlerdir. Başka bir çalışmada ise Trieste Körfezi (italya) kıyılarından toplanan $M$. galloprovincialis midyesinde $\mathrm{Cr}, \mathrm{Mn}, \mathrm{Cu}$, Fe ve $\mathrm{Zn}$ metal içeriklerinin ilkbaharda alınan örneklerde daha fazla olduğunu belirterek bu durumu ilkbahardaki üreme dönemi ile açıklamışlardır (Bongiorno ve ark., 2015).

Kepez kıyılarından örneklenen midye dokularında total protein (TP) miktarı ilkbaharda sonbahara oranla düşük bulunmuştur. İstatistiksel olarak dokular arasında karşılaştırma yapıldığında, en yüksek TP miktarı hepatopankreas dokusunda bulunmuştur (ilkbahar 22.06 \pm 3.21 , sonbahar 23.24 \pm 3.22 ) $(p<0.05)$. Mevsimsel olarak karşılaştırma yapıldığında ise solungaç dokusunda iki mevsim arasında anlamlı bir fark bulunurken (ilkbahar $20.03 \pm 1.80$, sonbahar $22.92 \pm 2.39)(p<0.05)$, kas ve hepatopankreas dokularındaki TP miktarında mevsimlere göre anlamlı bir fark görülmemiştir (Şekil 1).

SOD aktivitesine bakıldığında, solungaç dokusunda ilkbaharda (11.85 \pm 2.01$)$ sonbahara (4.36 \pm 0.66$)$ oranla anlamlı bir fark bulunmuştur $(p<0.05)$, hepatopankreas dokusunda önemli bir değişiklik yoktur. Antioksidan enzimlerin aktivitesi, toksik bileşiklere maruz kalma süresi ve bu maddelerin derişiminin yanı sıra, türlerin hassasiyetine bağlı olarak da artış veya azalma gösterebilir. Ortamda bulunan ağır metallerin hepatopankreas dokusunda tespit edilen SOD aktivitesinde değişikliğe yol açmaması, maruz kalınan derişimin enzim aktivitesini etkileyebilecek düzeyde olmamasına bağlanabilir (Aslan, 2010).

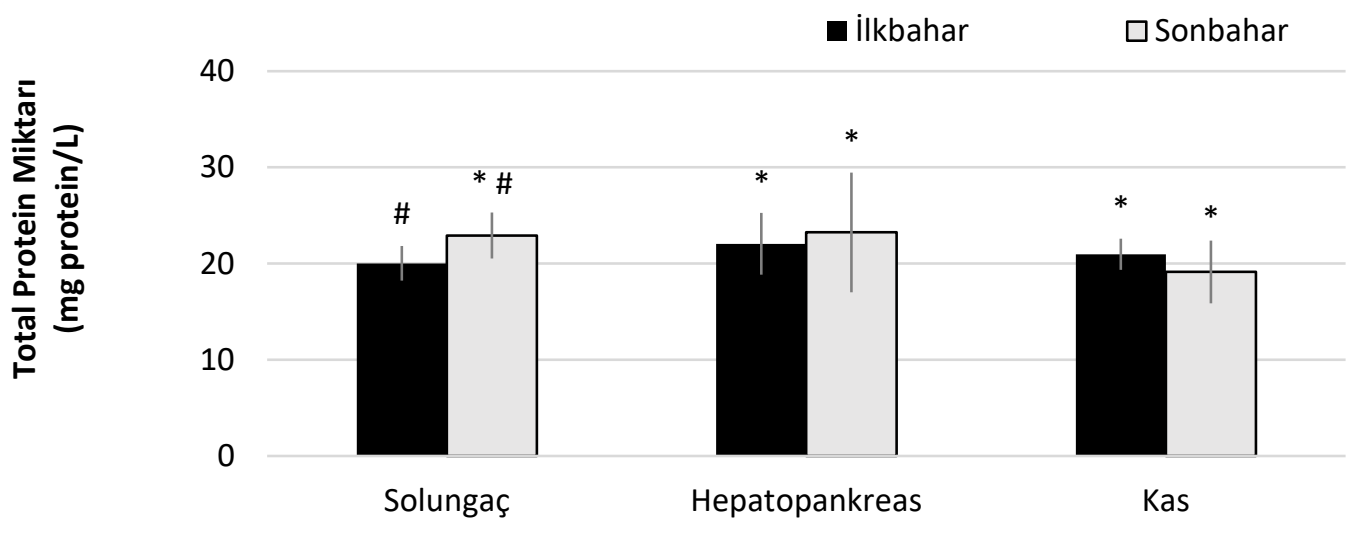

Şekil 1. Total protein miktarlarının mevsimlere bağlı olarak değişimi.

* Dokular arasındaki, \# Mevsimlere göre anlamlı farklılıklar gösterilmiştir $(p<0.05)$.

Çalışmada, solungaç dokusunda gözlenen anlamlı düşüş, artan $\mathrm{Pb}$ ve $\mathrm{Cu}$ ağır metalleri ile tetiklenmiş veya organizma için gerekli olan Fe ve $\mathrm{Zn}$ metallerinin düşmesi de oksidatif strese yol açmış olabilir. Mevcut çalışmada, en yüksek SOD aktivitesi kas dokusunda sonbaharda (19.56 \pm 2.35$)$ ilkbahara $(14.72 \pm 1.64)$ oranla anlamlı bir artış göstermiştir ( $p<0.05)$ (Şekil 2). Diğer dokuların aksine Cd konsantrasyonunun bu dokudaki artışı enzim aktivitesinin artmasını etkilemiş olabileceği gibi $\mathrm{Pb}$ ve $\mathrm{Cu}$ miktarlarındaki düşüş, Fe ve $\mathrm{Zn}$ miktarlarındaki artış da SOD enzim aktivitesinde değişikliğe sebep olmuş olabilir.

CAT enzim aktivitesi, hepatopankreas ve solungaç dokularında sonbahar mevsiminde (29.64 $\pm 4.16, \quad 20.18 .28 \pm 2,51) \quad$ ilkbahara
(53.13 $\pm 5.98,53.28 \pm 7,57)$ oranla anlamlı bir düşüş görülürken, kas dokusunda ise artış söz konusudur (ilkbahar 72.14 \pm 9.56 , sonbahar $91.78 \pm 5.28)$. Dokulara bağlı olarak yapılan istatistiksel karşılaştırmada ise, ilkbaharda örneklenen midyelerin solungaç ve hepatopankreas dokuları ile kas dokusu arasında anlamlı farklılıklar tespit edilmiştir $(p<0.05)$ (Şekil 3). Solungaç ve hepatopankreasta CAT aktivitesinin ilkbaharda daha yüksek çıktığı diğer çalışmalarda da ortaya konmuştur (Viarengo ve ark., 1991; Santovito ve ark., 2005; Valavanidis ve ark., 2007). Oksijenli solunum yapan her canlı sürekli olarak süperoksit radikali, hidroksil radikalleri ve $\mathrm{H}_{2} \mathrm{O}_{2}$ gibi reaktif oksijen türlerini (ROT) üretir. Toksik kirleticilere maruz kalan organizmalarda eksojen ve endojen kaynaklı 
ROT'lar arasında bir dengesizlik oluşarak, oksidatif hasara ya da antioksidan savunma sistemlerinde zayıflamaya sebep olabilir (Valavanidis ve ark., 2007). SOD, CAT gibi enzimatik antioksidanları içeren savunma sistemleri de, oluşabilecek ROT hasarlarını azaltacak yönde çalışır (Van der Oost ve ark., 2003). Cancio ve ark. (1999), M. galloprovincialis türünde bir yıllık periyotta CAT enzim aktivitelerine bakmışlar ve CAT aktivitesi ilkbahar ayları boyunca Nisandan Hazirana kadar oldukça yüksek görülürken, Temmuzdan Şubat ayına kadar düşük seviyelerde gözlenmiştir. Çalışma sonunda bu durumun midyelerin beslenmesiyle doğru orantılı olduğu, besin alımının mevsimlere bağlı değişmesiyle kimyasal parametrelerin değiştiği kaydedilmiştir. Bochetti ve ark. (2008), Tapes philippinarum ve $M$. galloprovincialis türlerinde mevsimsel değişimininin etkisini SOD, CAT antioksidanları üzerinde bakmışlar ve aktivitelerinin ilkbahar ve yaz aylarında düştüğünü belirlemişlerdir. Çalışmada, mevsimsel değişimin sıcaklıktan ziyade sudaki kirlilik düzeyindeki değişiklikten kaynaklanabileceği öne sürülmüştür. Yapılan çalışmada da solungaç ve hepatopankreasta antioksidan düzeyleri farklılık göstermekte ve bu farklılık söz konusu dokuların kirliliğe eşit miktarda maruz kalmamalarından kaynaklandığı düşünülmektedir.

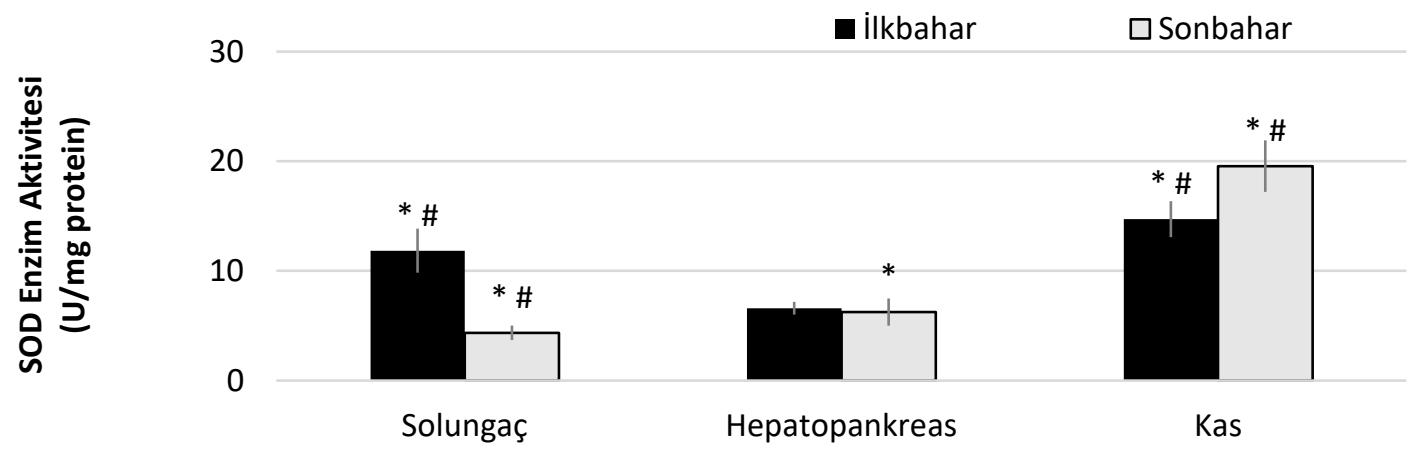

Şekil 2. SOD enzim aktivitesinin mevsimlere bağlı olarak değişimi.

* Dokular arasındaki, \# Mevsimlere göre anlamlı farklılıklar gösterilmiştir $(p<0.05)$.

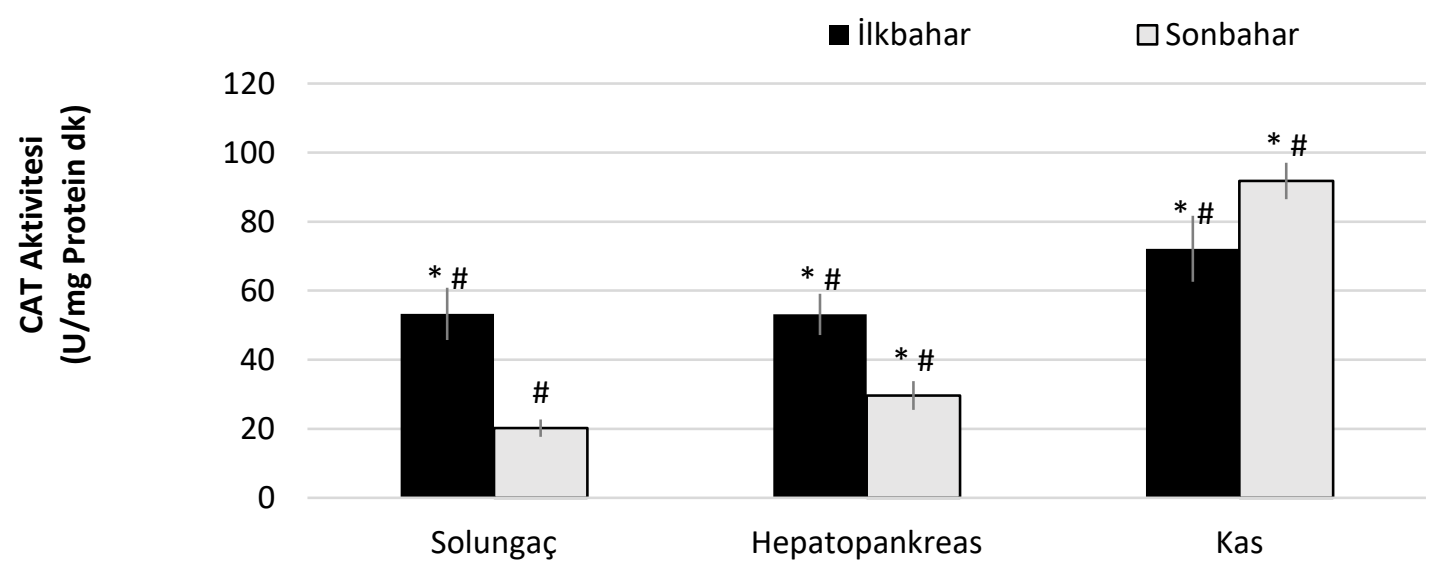

Şekil 3. CAT aktivitesinin mevsimlere bağlı olarak değişimi.

* Dokular arasındaki, \# Mevsimlere göre anlamlı farklılıklar gösterilmiştir $(p<0.05)$.

\section{Sonuç ve Öneriler}

$\mathrm{Bu}$ çalışmada, Kepez (Çanakkale) bölgesindeki ağır metal kirliliğinin midye $M$. galloprovincialis solungaç, hepatopankreas ve kas dokularındaki TP, SOD ve CAT düzeylerini mevsimlere ve dokulara göre nasıl değiştirdiği araştırımıştır. Farklı dokulardaki antioksidan 
enzim aktivitelerinin kirlilik düzeyinin yanı sıra mevsimsel olarak değiştiği ortaya konmuştur.

Antioksidanların biyoizleme çalışmalarda yaygın olarak kullanıldıkları bilinmektedir. Bu maddelerin kirliliğin yoğun olduğu bölgelerde yüksek miktarda ölçülmesi, oksidatif strese neden olan bileşiklerin detoksifikasyonunda oynadıkları kilit rol ile bağlantılıdır. Ağır metallerin çift kabuklular üzerindeki toksik etkilerini belirlemek, kirletici düzeylerinin insanlarda neden olacağı toksik etkileri öngörmeye yardımcı olacaktır.

\section{Teşekkür}

Bu çalışma, Çanakkale Onsekiz Mart Üniversitesi, Bilimsel Araştırma Projeleri Koordinasyon Birimince (BAP) FYL-2015-413 numaralı projeden desteklenmiştir.

\section{Kaynaklar}

Aebi, H. 1984. Catalase in vitro. Methods of Enzymology, 105: 121-126.

Aslan, E. 2010. İzmir Körfezi'ndeki Kara Midyelerinin (Mytilus galloprovincialis) ve Bazı Balık Türlerinin Farklı Organ ve Dokularındaki $210 \mathrm{Po}$ Konsantrasyonu ile Lipid Peroksidasyonu (LPO), $\mathrm{H}_{2} \mathrm{O}_{2}$ ve Prolin Arasındaki Korelasyonun Incelenmesi. Yüksek Lisans Tezi, Ege Üniversitesi.

Bocchetti, R., Lamberti, C.V., Pisanelli, B., Razzetti, E.M., Maggi, C., Catalano, B., Sesta, G., Martuccio, G., Gabellini M., Regoli F. 2008. Seasonal variations of exposure biomarkers, oxidative stress responses and cell damage in the clams, Tapes philippinarum, and mussels, Mytilus galloprovincialis, from Adriatic Sea. Marine Environmental Research, 66: 24-26.

Bongiorno, T., Lacumin, L., Tubaro, F., Marcuzzo, E., Sensidoni, A., Tulli, F. 2015. Seasonal changes in technological and nutritional quality of Mytilus galloprovincialis from suspended culture in the Gulf of Trieste (North Adriatic Sea). Food Chemistry, 173: 355-362.

Bradford, M.M. 1976. A rapid and sensitive method for the quantitation of microgram quantities of protein utilizing the principle of protein-dye binding. Analytical Biochemistry, 72: 248-254.

Brenneisen, P., Steinbrenner, H., Sies, H. 2005. Selenium, oxidative stress, and health aspects. Molecular Aspects Medicine, 26:
256-267.

Cancio, I., Cajaraville, M.P. 1999. Seasonal variation of xanthine oxidoreductase activity in the digestive gland cells of the mussel Mytilus galloprovincialis: A biochemical, histochemical and immunochemical study. Biology of the Cell, 91: 605-615.

Di Giulio, R.T., Washburn, P.C., Wenning, R.J., Winston, G.W., Jewell, C.S. 1989. Biochemical responses in aquatic animal: A review of determinants of oxidative stress. Environmental Toxicology and Chemistry, 8: 1103-1123.

EFSA, 2015. EFSA panel on contaminants in the food chain (CONTAM). Call for continuous collection of chemical contaminants occurrence data in food and feed. http://www.efsa.europa.eu/en/data/call /datex101217.htm.

Ekici, L., Sağdıç, O. 2008. Serbest radikaller ve antioksidan gıdalarla inhibisyonu. Gıda Dergisi, 33(5): 251-260.

Flöhe, L., Ötting, F. 1984. Superoxide dismutase assays. Methods of Enzymology, 105: 93104.

Fox, P.F., McSweeney, P.L.H., Lynch, C.M. 1998. Significance of non-starter lactic acid bacteria in cheddar cheese. Australian Journal of Dairy Technology, 53: 83-89.

Kayhan, F.E., Muşlu, M.N., Koç, N.D. 2009. Bazı ağır metallerin sucul organizmalar üzerinde yarattığı stres ve biyolojik yanitlar. Journal of Fisheries Sciences.com, 3(2): 153-162.

Livingstone, D.R., Forlin, L., George, S. 1994. Molecular biomarkers and Toxic Consequences of Impact by Organic Pollution in Aquatic Organisms. In: Sutcliffe D.W., eds. Water quality and stress indicators in marine and freshwater systems: Linking levels of organization. Freshwater Biological Association, Ambleside, UK, pp. 11711254.

Manduzio, H., Monsinjon, T., Rocher, B., Leboulenger, F., Galap, C. 2003. Characterization of an inducible isoform of the $\mathrm{Cu} / \mathrm{Zn}$ superoxide dismutase in the blue mussel Mytilus edulis. Aquatic Toxicology, 64: 73-83.

Matés, JM., Pérez-Gómez, C., De Castro, N.I. 1999. Antioxidant enzymes and human 
diseases. Clinical Biochemistry, 32 (8): 595-603.

Miniero, R., Ceretti, G., Cherin, E., Dellatte, E., De Luca, S., Ferri, F., Fulgenzi, A., Grim, F., Lacovella, N., Di Domenico, A. 2003. Correlation between PCDD and PCDF levels in sediments and clams (Tapes sp.) in the Venice Lagoon. Organohalogen Compounds, 62: 144-147.

Nawar, W.W. 1996. Lipids. In Food Chemistry, Fennema-Ed O.R., Dekker M., New York, pp. 225-319.

Olsson, P.E., Kling, P., Hogstrand, C. 1998. Mechanisms of Heavy Metal Accumulation and Toxicity in Fish. In: Langston W.J., Bebianno B.J., Eds. Metal metabolism in aquatic environments. London, UK. Pp. 321- 337.

Orbea, A., Ortiz-Zarragoitia, M., Sole, M., Porte, C., Cajaraville, M.P. 2002. Antioxidant enzymes and peroxisome proliferation in relation to contaminant body burdens of PAHs and PCBs in bivalve mollucs, crabs and fish form the Urdaibai and Plentzia Estuaries (Bay of Biscay). Aquatic Toxicology, 58: 75-98.

Özden, S. 2005. Çanakkale Boğazı ve Çevresindeki Bazı Midye ve Alg Türlerinin Ağır Metal Düzeylerinin Belirlenmesi. Çanakkale Onsekiz Mart Üniversitesi, Yüksek Lisans Tezi.

Özden, S. 2013. Gelibolu Yarımadası ve Saroz Körfezi Kıyılarında Askıda Katı Madde, sediment, Mytilus galloprovincialis ve Ulva rigida'da Ağır Metal Düzeylerinin Araştırılması. Çanakkale Onsekiz Mart Üniversitesi, Fen Bilimleri Enstitüsü, Su Ürünleri Anabilim Dalı, Doktora Tezi.

Rayment, G.E., Barry, G. 2000. Indicator tissues for heavy metal monitoring - additional attributes. Marine Pollution Bulletin, 41: 353-358.

Richir, J., Gobert S. 2014. A reassessment of the use of Posidonia oceanica and Mytilus galloprovincialis to biomonitor the coastal pollution of trace elements: New tools and tips. Marine Pollution Bulletin, 89(1-2): 390-406.

Santovito, G., Piccinni, E., Cassini, A., Irato, P., Albergoni, V. 2005. Antioxidant responses of the mediterranean mussel, Mytilus galloprovincialis, to environmental variability of dissolved oxygen. Comparative Biochemistry and Physiology Part C, 140: 321-329.

Schuyer, M., Berns, E.M. 1999. Is TP53 dysfunction required for BRCA1associated carcinogenesis? Molecular Cell Endocrinology, 155:143-152.

Siemer, D.D., Koteel, P., Jaiwala, V. 1976. Optimization of arsine generation in atomic absorption arsenic determinations. Analytical Chemistry, 48(6): 21-24.

Speranza, M.J., Bagley, A.C., Lynch, B.E. 1993. Cells enriched for catalase are sensitized to the toxicities of bloomycin, adriamycin and paraquat. Journal of Biyology and Chemistry, 268: 39-43.

Uysal, H. 1970. Türkiye Sahillerinde Bulunan Midyeler Mytilus galloprovincialis, Lamarc Üzerinde Biyolojik ve Ekolojik Araştırmalar. Ege Üniversitesi. Fen Fakültesi, illmi Raporlar Serisi, 79.

Valavanidis, A., Vlahogianni, T., Dassenakis, M., Scoullos, M.J. 2007. Integrated use of biomarkers (Superoxide dismutase, catalase and lipid peroxidation) in mussels Mytilus galloprovincialis for assessing heavy metals pollution in coastal areas from the Saronikos Gulf of Greece. Marine Pollution Bulletin, 54: 1361-1371.

Van Der Oost, R., Beyer, J., Vermeulen, N.P.E. 2003. Fish bioaccumulation and biomarkers in environmental risk assessment: A Review. Environmental Toxicology and Pharmacology, 13: 57149.

Viarengo, A., Canesi, L., Pertica, M., Livingstone, D.R. 1991. Seasonal variations in the antioxidant defense systems and lipid peroxidation of the digestive gland of mussels. Comparative Biochemistry and Physiology Part C, 100 (1/2): 187-190.

Yining, B., Wenbo, Z., Zheng, Z., Zhengshan Wang, Z. 2011. Antioxidant property in vivo of cheese whey enzymatic hydrolysates. The 5 th International Conference on Bioinformatics and Biomedical Engineering, May 2011, Wuhan, China 1-4 p.

Yüzügüllü, Y., Özgel, B.Z. 2013. Çift aktiviteli katalaz-fenol oksidazın ve diğer katalazların gıda sanayisindeki önemi. Gıda, 38(2): 111-118. 